\title{
Synthesis of Highly Oxygenated Bicyclic Carbasugars. Remarkable Difference in the Reactivity of the D-gluco and D-xylo- Derived Trienes
}

\author{
Grzegorz Witkowski, Mykhaylo A. Potopnyk, Karolina Tiara, Anna Osuch-Kwiatkowska \\ and Stawomir Jarosz *(iD) \\ Institute of Organic Chemistry, Polish Academy of Sciences, Kasprzaka 44/52, 01-224 Warsaw, Poland; \\ grzegorz.witkowski@icho.edu.pl (G.W.); mpotopnyk@icho.edu.pl (M.A.P.); karolina.tiara@icho.edu.pl (K.T.); \\ aosuch@icho.edu.pl (A.O.-K.) \\ * Correspondence: slawomir.jarosz@icho.edu.pl \\ Academic Editor: László Somsák \\ Received: 3 July 2020; Accepted: 22 July 2020; Published: 24 July 2020 \\ check for \\ updates
}

\begin{abstract}
Tri-O-benzyl-D-xylopyranose was used as a starting material in the preparation of the corresponding triene, which underwent smooth cyclization to a polyhydroxylated hydrindane, as a single diastereoisomer. The analogous triene prepared from D-glucose did not undergo any cyclization even under high pressure.
\end{abstract}

Keywords: bicyclic sugar mimetics; stereoselective synthesis; Diels-Alder reaction; Wittig-type reaction

\section{Introduction}

Carbasugars are glycomimetics obtained through a substitution of the endocyclic oxygen atom with a methylene group [1,2]. Due to their similarity to carbohydrates, these compounds often possess interesting biological properties, e.g., they may act as glycosidase inhibitors [3-5]. Some of these compounds found an application in medicine; for example, acarbose is commercialized to treat obesity and type 2 diabetes mellitus [6] and validamycin is an antibiotic [7]. Elaboration of the convenient synthetic methods for the preparation of carbobicyclic sugar mimetics is one of the leading trends in our laboratory [8]. We have proposed a useful route to polyhydroxylated decalins (such as 5) from sugar allyltins as shown in Scheme 1 [9]. The model synthesis was initiated from D-gluco-derivative 1, which-upon treatment with mild Lewis acid (preferably $\mathrm{ZnCl}_{2}$ ) -afforded dienoaldehyde 2 with the E-configuration across the internal double bond. This compound was converted into phosphonate 3 and-by the Horner-Wadsworth-Emmons (HWE) reaction with the corresponding aldehyde-into triene 4, subsequently cyclized to 5 . The methodology proposed in Scheme 1 allowed the preparation of a number of diastereoisomeric polyhydroxylated bicyclic derivatives in optically pure form starting from different sugars: D-glucose, D-mannose, and D-galactose [9-12].

It is known that polyhydroxylated decalins might have significant biological activity [13-15], thus there is an interest in the preparation of such targets. Our methodology, however, starting from organostannanes-being assumed to be highly toxic-cannot be used for the preparation of potential therapeutics. Other, environmentally friendly method(s), for the synthesis of such important derivatives is needed.

We have proposed an efficient method for the stereoselective preparation of sugar dienes with the $E$ or $Z$ geometry across the internal double bond (8- $E$ or 8-Z; Scheme 2 ) from D-glucosep-derivative 6 (via intermediate 7) [16]. These compounds could be eventually used as convenient precursors for the 
synthesis of bicyclic carbasugars. Wittig-type reaction of hemiacetal 8 could provide appropriate triene 9 which, via a [4+2]-cyclization, should afford carbobicyclic derivatives (e.g., 10; Scheme 2).



Scheme 1. Synthesis of polyhydroxylated decalins from sugar allyltins.

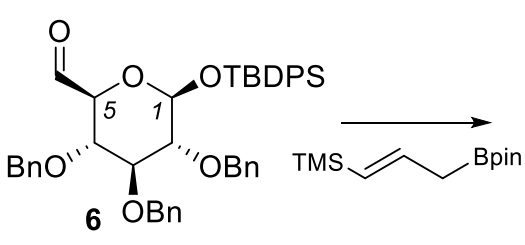

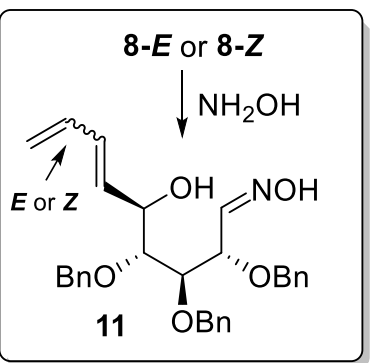




1. $\mathrm{H}_{2} \mathrm{SO}_{4}, \mathrm{THF}$

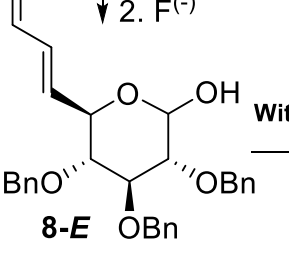



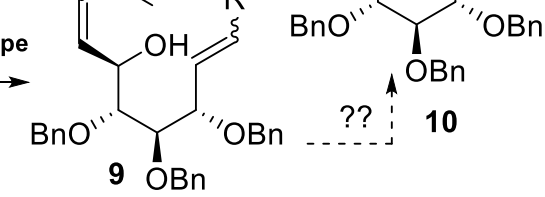

Scheme 2. Stereoselective synthesis of sugar dienes $8-E / 8-Z$ and their reactivity.

However, treatment of compounds 8 (either $\boldsymbol{E}$ or $\mathbf{Z}$ ) with phosphoranes (Wittig reaction) or phosphonates (HWE reaction) did not give any expected product 9. Further, these hemiacetals did not react even with simplest organometallic species such e.g., Grignard reagents. The only process which could be realized, was the reaction with hydroxylamine providing the corresponding oxime $\mathbf{1 1}$ in good yield (Scheme 2).

\section{Results and Discussion}

Since the intermediate 9 (see Scheme 2) could not be obtained from our diene 8 , we changed the concept and design to introduce the diene system at the anomeric position and then the olefinic unit at the terminal position; this triene can be called "inverted" comparing to triene 9. This strategy is exemplified on Scheme 3 for D-glucose derivative 12. We reasoned that this approach would be more profitable, the problems encountered for diene 8 could be avoided, and we would be able to obtain triene $\mathbf{1 3}$ in reasonable yield.

This triene should also cyclize to the bicyclic system in the Diels-Alder reaction. This assumption is based on the results of Evans, who presented an efficient and highly diastereoselective cyclization of similar triene with the activating $N$-acyloxazolidinone unit at the olefinic part (14 $\rightarrow \mathbf{1 5}$; Scheme 4) [17-19]. 


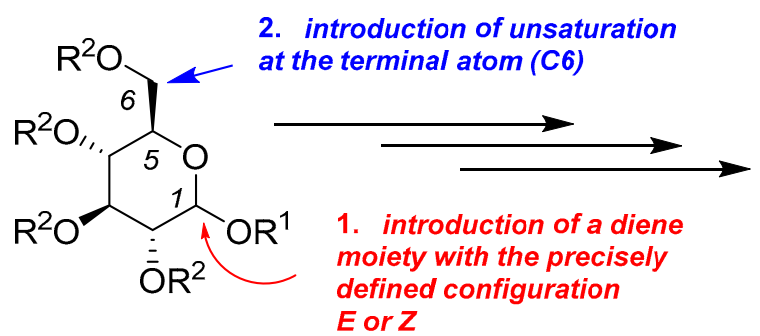

12



$13 E$ or $Z$ - diene

Scheme 3. A concept of the synthesis of 'inverted' sugar trienes from D-glucose.<smiles>C=C/C=C\CCCC/C=C/C(=O)N1C(=O)OC[C@H]1Cc1ccccc1</smiles>

Scheme 4. Cyclization of the triene 14 by Evans et. al. ref. [17-19].

\subsection{Synthesis of Derivatives of D-Glucose with the Diene System Located at the C1}

The synthesis of polyhydroxylated trienes in our case was initiated from the easily available di-thioacetal 16, prepared from free glucose according to $\mathrm{Yu}$ and coworkers [20]. The $\mathrm{OH}$ group at the terminal position in $\mathbf{1 6}$ was protected as a TBDPS ether, the carbonyl group at the $\mathrm{C} 1$ was regenerated according to reference [21], and the resulting aldehyde 17 was reacted with allyltitanium reagent 18 [22], providing the mixture of silanols 19 with the anticipated $[16,22,23]$ anti-configuration (Scheme 5).

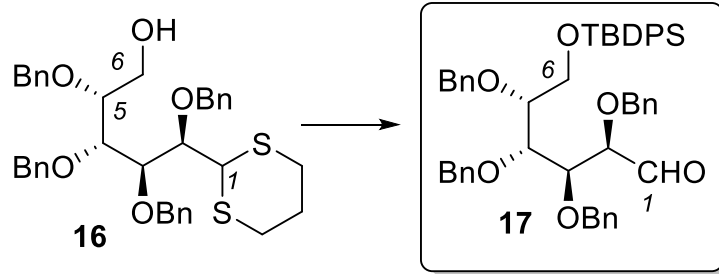

Scheme 5. Synthesis of silanol 19.



anti isomers

$\beta$-Hydroxysilane 19 was subjected to the Peterson olefination under acidic and, independently, basic conditions which should lead to the corresponding dienes with the $E$ or Z-configuration across the internal double bond. However, treatment of 19 with acids $\left(\mathrm{H}_{2} \mathrm{SO}_{4}\right.$ or $\left.\mathrm{BF}_{3}\right)$ did not provide diene 20; the starting material remained unchanged (Scheme 6).

We reasoned that this resistance to the elimination of silanol might result from the presence of the bulky substituent located at the terminal position (TBDPS ether), so deprotection of this position might solve the problem. Treatment of $\mathbf{1 9}$ with fluoride anion not only removed this silyl group but also induced the Peterson olefination providing the Z-diene 21. This Z-diene was thus used to test our hypothesis (shown in Scheme 3) of the convenient preparation of the "inverted" trienes and their subsequent application in the synthesis of bicyclic derivatives via a cyclization reaction as reported by Evans for triene $\mathbf{1 4}$ (cf. Scheme 4). 




Scheme 6. (a) TEMPO (2,2,6,6-tetrametylopiperydyno-1-oksyl), TCICA (trichloroisocyanuric acid), $0{ }^{\circ} \mathrm{C}$ to rt., 15 min.; (b) 23, LiBr, i-Pr 2 NEt, MeCN, rt., 18 h.

Alcohol 21 was oxidized to the corresponding aldehyde 22 which reacted with phosphonate 23 [24], to afford triene $\mathbf{2 4}$ with the $E$-configuration across the newly created double bond (Scheme 6). This triene was subjected to the cyclization induced by $\mathrm{Me}_{2} \mathrm{AlCl}$; no reaction was, however, noticed. Application of other Lewis acids, as well as, high pressure (10 kbar) also did not give any positive result. This lack of cyclization was very surprising, especially in the context of the results obtained by Evans.

We prepared also two other trienes: 25 and 26 by reaction of aldehyde 22 with appropriate phosphoranes: $\mathrm{Ph}_{3} \mathrm{P}=\mathrm{CHCO}_{2} \mathrm{Me}$ and $\mathrm{Ph}_{3} \mathrm{P}=\mathrm{CHCO}_{2} \mathrm{Me}$. None of the resulting trienes, however, underwent cyclization (Scheme 6).

Why could the cyclization of compounds-similar to those successfully used in Evans' synthesis-not be realized? Is it a result of only the different configuration across the double bond in a diene system ( $Z$ in 24 in our case vs. $E$ in $\mathbf{1 4}$ in Evans case)? Or maybe other reasons are responsible for that strange result. This phenomenon is not clear.

We turned, therefore, our attention to shorter analogs being precursors of perhydroindane derivatives.

\subsection{Synthesis of Derivatives of D-Xylose with the Diene System at the $C 1$}

The synthesis was initiated from known lactone 27 [25], obtained by an oxidation of 2,3,4-tri-O-benzyl-D-xylose. It was reacted with the in situ generated complex of $\mathrm{Me}_{3} \mathrm{Al}$ and $\mathrm{N}, \mathrm{O}$-dimethylhydroxylamine which provided the Weinreb amide 28. Since this compound was relatively unstable (easily underwent decomposition to 27), it was converted immediately into silylated derivative $\mathbf{2 9}$ and then into aldehyde $\mathbf{3 0}$. Reactivity of $\mathbf{3 0}$ was similar to the previously obtained derivatives. Its conversion into $\mathbf{3 1}$ followed the same route as for D-glucose derivatives (depicted in Scheme 1); this silanol (31) was also unreactive under the acidic conditions and underwent conversion into Z-diene 32 with the simultaneous removal of the silyl block upon treatment with fluoride anion 
(Scheme 7). The configuration of the internal double bond in the diene part was proven by ${ }^{1} \mathrm{H}$ NMR data in which the coupling constant $J=11.2 \mathrm{~Hz}$ was observed (see Scheme 7).

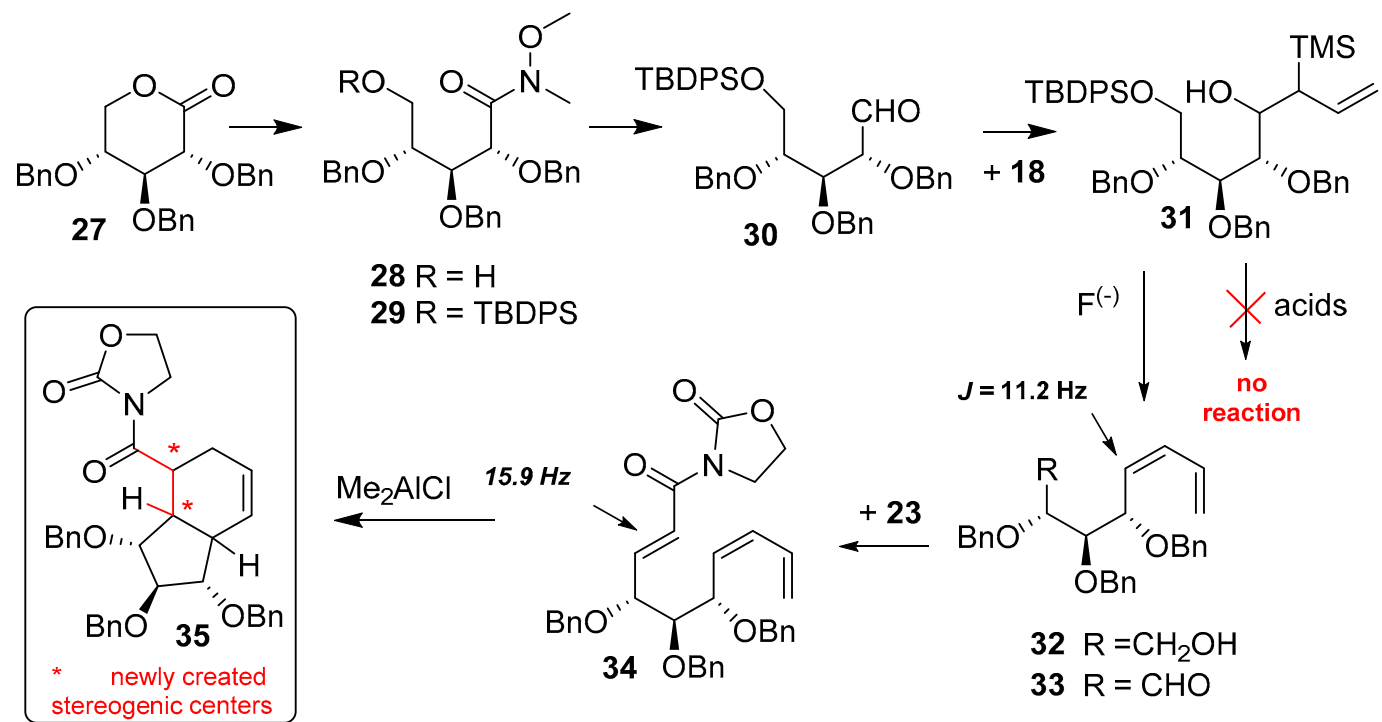

Scheme 7. Stereoselective synthesis of bicyclic derivative 35 from D-xylose.

Compound 32 was converted into aldehyde 33 and further into triene 34, with the E-configuration across the newly created double bond $(J=15.9 \mathrm{~Hz})$. Cyclization of this triene induced with $\mathrm{Me}_{2} \mathrm{AlCl}$ provided bicyclic compound 35 as a single stereoisomer (Scheme 3); only two olefinic signals at $\delta=128.0$ and 124.3 ppm were seen in the ${ }^{13} \mathrm{C}$ NMR spectrum.

The configuration of the product was assigned by the Nuclear Overhauser Effect (NOE) measurement (Figure 1).


Figure 1. The NOE values of bicyclic product 35.

Small NOE values between the H1-H7a and H3-H3a confirmed structure 35 and-at the same time-excluded the alternative one: $35 \mathrm{a}$ in which the strong $\mathrm{H} 1-\mathrm{H} 7 \mathrm{a}$ and $\mathrm{H} 3-\mathrm{H} 3 \mathrm{a}$ interaction should have been observed.

\section{Materials and Methods}

\subsection{General}

NMR spectra were recorded in $\mathrm{CDCl}_{3}$ (internal $\mathrm{Me}_{4} \mathrm{Si}$ ) with a Varian AM-600 $\left(600 \mathrm{MHz}{ }^{1} \mathrm{H}\right.$, $150 \mathrm{MHz}{ }^{13} \mathrm{C}$ ) spectrometer (Sugar Land, TX, USA) at rt. Chemical shifts $(\delta)$ are reported in ppm relative to $\mathrm{Me}_{4} \mathrm{Si}(\delta 0.00)$ for ${ }^{1} \mathrm{H}$ and residual chloroform $(\delta 77.00)$ for ${ }^{13} \mathrm{C}$. All significant resonances (carbon skeleton) were assigned by COSY $\left({ }^{1} \mathrm{H}_{-}{ }^{1} \mathrm{H}\right), \mathrm{HSQC}\left({ }^{1} \mathrm{H}_{-}{ }^{13} \mathrm{C}\right)$, and $\mathrm{HMBC}\left({ }^{1} \mathrm{H}_{-}{ }^{13} \mathrm{C}\right)$ correlations. The relative configuration of the stereogenic centers was assigned on the basis of 1D-NOESY spectra. 
Mass spectra (ESI) were recorded with an Applied Biosystems 4000 Q-TRAP (low resolution) (Toronto, ON, Canada) and Waters AutoSpec Premier (Waters, Milford, MA, USA) or Waters MALDISynapt G2-S HDMS (high resolution) spectrometers (Manchester, UK). HPLC analyses were conducted on Merck-Hitachi apparatus (Darmstadt, Germany) equipped with Merck LiChrospher 100 RP-18 $(250 \times 0.4 \mathrm{~mm}, 5 \mu \mathrm{m})$ column and UV detector. Column chromatography was performed on silica gel 60 (70-230 mesh, Merck. Flash chromatography was performed on Buchi glass columns packed with silica gel 60 (230-400 mesh, Merck), using Knauer Smartline system with a Buchi fraction collector. Reagents were purchased from Sigma-Aldrich (St. Louis, MO, USA), Alfa Aesar (Tianjin, China) or ABCR (Karlsruhe, Germany), and used without purification. Thin-layer chromatography was carried out on silica gel $60 \mathrm{~F}_{254}$ (Merck). The organic solutions were dried over $\mathrm{MgSO}_{4}$.

The scans of the NMR data for all compounds are provided as Supplementary Materials.

\subsubsection{2,3,4,5-Tetra-O-benzyl-6-O-tert-butyl-diphenylsilyl-D-glucose 17}

To a cooled to $0{ }^{\circ} \mathrm{C}$ solution of 2,3,4,5-tetra-O-benzyl-D-glucose propane-1,3-diyl dithioacetal [20] (16; $21.89 \mathrm{~g} ; 34.7 \mathrm{mmol})$ and imidazole $(4.74 \mathrm{~g}, 69.4 \mathrm{~g}, 2.0 \mathrm{eq})$ in methylene chloride (300 mL), tert-butyl-diphenylsilyl chloride $(9.6 \mathrm{~mL}, 37.5 \mathrm{mmol}, 1.1$ equiv.) was added dropwise within $1 \mathrm{~h}$ and the mixture was stirred overnight at room temperature. Water $(150 \mathrm{~mL})$ was added, the layers were separated and the organic solution was washed with $1 \mathrm{M} \mathrm{H}_{2} \mathrm{SO}_{4}(100 \mathrm{~mL})$ and water $(100 \mathrm{~mL})$, dried, concentrated, and the crude product was isolated by column chromatography (hexanes-ethyl acetate $7: 1 \rightarrow 3: 1)$ to afford the 6-O-protected derivative $(27.47 \mathrm{~g}$; $91 \%)$ as an oil.

${ }^{1} \mathrm{H}$ NMR $\delta: ~ 7.69-7.52(\mathrm{~m}, 4 \mathrm{H}), 7.48-7.15(\mathrm{~m}, 26 \mathrm{H}), 4.88(\mathrm{~d}, J=11.5 \mathrm{~Hz}, 1 \mathrm{H}), 4.76-4.57(\mathrm{~m}, 5 \mathrm{H}), 4.49(\mathrm{~d}, J$ $=11.2 \mathrm{~Hz}, 1 \mathrm{H}), 4.38(\mathrm{~d}, J=11.5 \mathrm{~Hz}, 1 \mathrm{H}), 4.23(\mathrm{~d}, J=4.8 \mathrm{~Hz}, 1 \mathrm{H}), 4.07(\mathrm{t}, J=5.2 \mathrm{~Hz}, 1 \mathrm{H}), 3.99-3.91(\mathrm{~m}$, $2 \mathrm{H}), 3.85-3.81(\mathrm{~m}, 1 \mathrm{H}), 3.69(\mathrm{dd}, J=6.2,4.6 \mathrm{~Hz}, 1 \mathrm{H}), 3.54(\mathrm{dt}, J=5.6,4.3 \mathrm{~Hz}, 1 \mathrm{H}), 2.87-2.74(\mathrm{~m}, 1 \mathrm{H})$, $2.77-2.53(\mathrm{~m}, 3 \mathrm{H}), 1.97-1.91(\mathrm{~m}, 1 \mathrm{H}), 1.91-1.81(\mathrm{~m}, 1 \mathrm{H}), 1.10(\mathrm{~s}, 9 \mathrm{H})$;

${ }^{13}$ C NMR $\delta: 138.9,138.7,2 \times 138.4,135.9-127.0,81.9,79.8,79.9,78.4,75.2,74.7,73.8,72.5,62.4,49.5,30.0$, $29.5,27.0,26.2,19.3$.

HR-MS: $m / z=868.3647$; calcd for $\mathrm{C}_{53} \mathrm{H}_{60} \mathrm{O}_{5} \mathrm{~S}_{2} \mathrm{SiNa}[\mathrm{M}+\mathrm{Na}]^{+}: 868.3651$.

To a solution of the above prepared compound ( $4.36 \mathrm{~g} ; 5.02 \mathrm{mmol}$ ) in $\mathrm{MeCN}: \mathrm{CH}_{2} \mathrm{Cl}_{2}: \mathrm{H}_{2} \mathrm{O}$ (8:1:1; $50 \mathrm{~mL}$ ), Dess-Martin reagent $(4.47 \mathrm{~g}, 10.0 \mathrm{mmol}, 2.0 \mathrm{eq})$ was added, the mixture was stirred at room temperature overnight, and concentrated. The residue was purified by column chromatography (hexanes-ethyl acetate 7:1 $\rightarrow 3: 1)$ affording the title product 17 (3.28 g; 84\%) (Figure 2), which was used immediately in the next step.



Figure 2. The structure of aldehyde 17.

LR-MS: $m / z=833\left[\mathrm{C}_{51} \mathrm{H}_{58} \mathrm{O}_{7} \mathrm{SiNa}(\mathrm{M}+\mathrm{MeOH}+\mathrm{Na})^{+}\right]$.

\subsubsection{Olefin 19}

Generation of the titanium reagent 18 : To a cooled to $-78^{\circ} \mathrm{C}$ solution of allyltrimethylsilane $(3.7 \mathrm{~g}$, $32.4 \mathrm{mmol}, 10.0 \mathrm{eq})$ in dry THF ( $32 \mathrm{~mL})$, a solution of $2.5 \mathrm{M} \mathrm{BuLi}$ in hexane (12 mL, $29.1 \mathrm{mmol}, 9.0 \mathrm{eq}$.) was added within $1 \mathrm{~h}$ with a syringe pump; after another $30 \mathrm{~min}$. the mixture became yellowish. Then, a solution of $1.0 \mathrm{M} \mathrm{ClTi}\left(\mathrm{O}^{i} \mathrm{Pr}\right)_{3}$ in methylene chloride $(29 \mathrm{~mL})$ was added within $30 \mathrm{~min}$ (syringe pump) and the red mixture was stirred for another $30 \mathrm{~min}$. 
To such prepared reagent $\mathbf{1 8}$, a solution of $\mathbf{1 7}(2.10 \mathrm{~g}, 3.19 \mathrm{mmol})$ in dry THF $(6.4 \mathrm{~mL})$ was added within $1 \mathrm{~h}$, the mixture was stirred overnight at $-78^{\circ} \mathrm{C}$ (using immersion cooler with temperature control Huber TC100E, temperature range -100 to $\left.+40{ }^{\circ} \mathrm{C}\right)$ and partitioned between water $(70 \mathrm{~mL})$ and ether $(70 \mathrm{~mL})$. The white precipitate was filtered off and discarded; the organic layer was separated, washed with brine, and concentrated to afford a crude mixture of (anticipated) anti-isomers, pure enough to be used in the next steps (Figure 3).

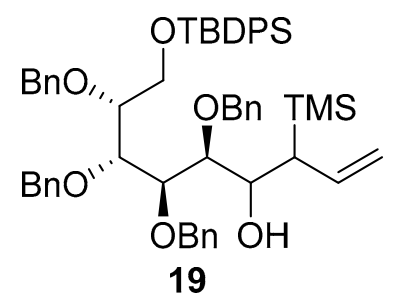

Figure 3. The structure of silanol 19.

LR-MS: $m / z=915\left[\mathrm{C}_{56} \mathrm{H}_{68} \mathrm{O}_{6} \mathrm{Si}_{2} \mathrm{Na}(\mathrm{M}+\mathrm{Na})^{+}\right]$.

\subsubsection{Dienoalcohol 21}

To a solution of crude 19 obtained above in THF $(16 \mathrm{~mL})$ a solution of $1.0 \mathrm{M}$ TBAF in THF $(16 \mathrm{~mL}$, $16.0 \mathrm{mmol}, 5.0$ eq.) was added and the mixture was stirred at room temperature overnight. Then it was concentrated and the residue was subjected to column chromatography (hexane-ethyl acetate, $92: 8 \rightarrow 36: 64)$ to afford the title product 21 (1.11 $\mathrm{g}, 73 \%$ over two steps) as an oil (Figure 4 ).



numbering of the atoms for the assignment of the NMR data

Figure 4. The structure of diene 21 and the numbering of the atoms.

${ }^{1} \mathrm{H}$ NMR $\delta: ~ 7.39-7.17 ~(m, 20 H$, arom.), 6.51 (ddd, $J=16.6,11.0$ and $10.1 \mathrm{~Hz}, 1 \mathrm{H}, \mathrm{H}-2), 6.29(\mathrm{t}, J=11.2 \mathrm{~Hz}$, $1 \mathrm{H}, \mathrm{H}-3), 5.46$ (t, $J=10.3 \mathrm{~Hz}, 1 \mathrm{H}, \mathrm{H}-4), 5.28$ (d, $J=16.7 \mathrm{~Hz}, 1 \mathrm{H}, \mathrm{H}-1), 5.11$ (d, J = 10.1 Hz, 1H, H-1' ), 4.86 $\left(\mathrm{d}, J=11.4 \mathrm{~Hz}, 1 \mathrm{H}, \mathrm{OC} \underline{H}_{2} \mathrm{Ph}\right), 4.73\left(\mathrm{~d}, J=11.4 \mathrm{~Hz}, 1 \mathrm{H}, \mathrm{OCH}_{2} \mathrm{Ph}\right), 4.68\left(\mathrm{~d}, J=11.5 \mathrm{~Hz}, 1 \mathrm{H}, \mathrm{OC} \underline{H}_{2} \mathrm{Ph}\right)$, 4.63-4.57 (m, 3H, H-5 and $\left.2 \times \mathrm{OC}_{2} \mathrm{Ph}\right), 4.49\left(\mathrm{~d}, J=11.6 \mathrm{~Hz}, 1 \mathrm{H}, \mathrm{OC} \underline{H}_{2} \mathrm{Ph}\right), 4.37(\mathrm{~d}, J=11.6 \mathrm{~Hz}, 1 \mathrm{H}$, $\left.\mathrm{OC} \underline{H}_{2} \mathrm{Ph}\right), 4.33\left(\mathrm{~d}, J=11.7 \mathrm{~Hz}, 1 \mathrm{H}, \mathrm{OC}_{2} \mathrm{Ph}\right), 3.90(\mathrm{t}, J=4.9 \mathrm{~Hz}, 1 \mathrm{H}, \mathrm{H}-8), 3.85$ (ddd, $J=12.0,5.4$, and $4.0 \mathrm{~Hz}, 1 \mathrm{H}, \mathrm{H}-9$ ), 3.77 (ddd, $J=11.7,6.9,4.0 \mathrm{~Hz}, 1 \mathrm{H}, \mathrm{H}-9^{\prime}$ ), 3.73 (dd, $J=6.1,4.4 \mathrm{~Hz}, 1 \mathrm{H}, \mathrm{H}-6$ ), 3.66 (dt, $J$ $=5.5$ and $4.0 \mathrm{~Hz}, 1 \mathrm{H}, \mathrm{H}-7), 2.15(\mathrm{dd}, J=6.9$ and $5.5 \mathrm{~Hz}, 1 \mathrm{H}, \mathrm{OH})$;

${ }^{13} \mathrm{C}$ NMR $\delta: 138.8,138.7$ and $2 \times 138.3$ (quat. benzyl), 134.2 (C-3), 131.9 (C-2), 128.6-127.6 (arom. and C-4), 120.4 (C-1), 81.9 (C-6), 79.7 (C-7), 79.3 (C-8), 75.6 (C-5), 75.2, 74.5, 71.7 and 70.5 (4×OC$\left.{ }_{2} \mathrm{Ph}\right), 60.8$ (C-9).

HR-MS: $m / z=587.2770$; calcd for $\mathrm{C}_{37} \mathrm{H}_{40} \mathrm{O}_{5} \mathrm{Na}[\mathrm{M}+\mathrm{Na}]^{+}: 587.2773$.

\subsubsection{Dienoaldehyde 22}

To a cooled to $0{ }^{\circ} \mathrm{C}$ solution of alcohol $21(350 \mathrm{mg}, 0.62 \mathrm{mmol})$ and TEMPO (1.0 mg; $\left.6.0 \mu \mathrm{mol}\right)$ in dry $\mathrm{CH}_{2} \mathrm{Cl}_{2}(8 \mathrm{~mL})$, trichloroisocyanuric acid (155 mg; $\left.0.66 \mathrm{mmol} ; 1.1 \mathrm{eq}\right)$ was added and the mixture was stirred for $15 \mathrm{~min}$. Then it was filtered through short pad of Celite, the filtrate was diluted with 
$\mathrm{Et}_{2} \mathrm{O}(6.0 \mathrm{~mL})$ and washed with $5 \% \mathrm{Na}_{2} \mathrm{~S}_{2} \mathrm{O}_{3}(2.0 \mathrm{~mL}), 1 \mathrm{M} \mathrm{NaOH}(5 \mathrm{~mL}), 1 \mathrm{M} \mathrm{H}_{2} \mathrm{SO}_{4}(5 \mathrm{~mL})$, and water $(3.0 \mathrm{~mL})$. The organic phase was dried and concentrated, and the crude aldehyde was used immediately in the next step (Figure 5).

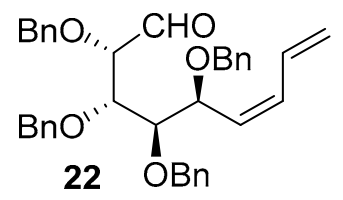

Figure 5. The structure of diene 19.

LR-MS: $m / z=617\left[\mathrm{C}_{38} \mathrm{H}_{42} \mathrm{NO}_{6} \mathrm{Na}(\mathrm{M}+\mathrm{MeOH}+\mathrm{Na})^{+}\right]$.

\subsubsection{Triene 24}

To a solution of aldehyde 22 (170 $\mathrm{mg}, 0.3 \mathrm{mmol})$ and phosphonate 23 [21] (120 $\mathrm{mg}$, $1.5 \mathrm{eq}$.$) in dry$ $\mathrm{CH}_{3} \mathrm{CN}$ (3 mL), LiBr (40.5 mg, $0.466 \mathrm{mmol}, 1.5 \mathrm{eq}$ ) was added followed by di-isopropylethylamine $(80 \mu \mathrm{L}, 0.466 \mathrm{mmol}, 1.5 \mathrm{eq})$ and the mixture was stirred for $20 \mathrm{~h}$. It was then concentrated and the crude product was purified by column chromatography (hexane 100\% then: hexane-ethyl acetate 92:8 $\rightarrow 36: 64$ ) (Figure 6).<smiles>[Z4]c1ccc(Br)cc1</smiles>

Figure 6. The structure of triene 24 and the numbering of the atoms.

${ }^{1} \mathrm{H}$ NMR $\delta: ~ 7.46(\mathrm{~d}, J=15.6,1 \mathrm{H}, \mathrm{H}-10), 7.35-7.16(\mathrm{~m}, 21 \mathrm{H}$, arom. and H-9), $6.51(\mathrm{ddd}, J=16.7,11.3$ and $10.1 \mathrm{~Hz}, 1 \mathrm{H}, \mathrm{H}-2), 6.27(\mathrm{t}, J=11.2 \mathrm{~Hz}, 1 \mathrm{H}, \mathrm{H}-3), 5.45(\mathrm{dd}, J=11.1$ and $9.7 \mathrm{~Hz}, 1 \mathrm{H}, \mathrm{H}-4), 5.25(\mathrm{~d}$, $J=16.7 \mathrm{~Hz}, 1 \mathrm{H}, \mathrm{H}-1), 5.09\left(\mathrm{~d}, J=10.1 \mathrm{~Hz}, 1 \mathrm{H}, \mathrm{H}-1^{\prime}\right), 4.84\left(\mathrm{~d}, J=11.5 \mathrm{~Hz}, 1 \mathrm{H}, \mathrm{OC} \underline{H}_{2} \mathrm{Ph}\right), 4.67-4.59(\mathrm{~m}$, $3 \mathrm{H}, 2 \times \mathrm{OCH}_{2} \mathrm{Ph}$ and $\left.\mathrm{H}-5\right), 4.56\left(\mathrm{~d}, \mathrm{~J}=11.7 \mathrm{~Hz}, 1 \mathrm{H}, \mathrm{OC}_{2} \mathrm{Ph}\right), 4.55-4.47\left(\mathrm{~m}, 2 \mathrm{H}, 2 \times \mathrm{OC}_{2} \mathrm{Ph}\right), 4.38-4.30$ $\left(\mathrm{m}, 3 \mathrm{H}, \mathrm{OC} \underline{\mathrm{H}}_{2} \mathrm{Ph}\right.$ and $\left.2 \times \mathrm{H}-13\right), 4.24(\mathrm{dd}, J=6.8$ and $5.6 \overline{\mathrm{Hz}}, 1 \mathrm{H}, \mathrm{H}-8), 4.14\left(\mathrm{~d}, J=11.4 \mathrm{~Hz}, 1 \mathrm{H}, \mathrm{OC} \underline{H}_{2} \mathrm{Ph}\right)$, $3.97(\mathrm{qdd}, J=11.1,8.9$ and $7.1 \mathrm{~Hz}, 2 \mathrm{H}, 2 \times \mathrm{H}-14), 3.81(\mathrm{dd}, J=5.6$ and $4.2 \mathrm{~Hz}, 1 \mathrm{H}, \mathrm{H}-7), 3.74(\mathrm{dd}, J=6.3$ and $4.2 \mathrm{~Hz}, 1 \mathrm{H}, \mathrm{H}-6)$;

${ }^{13} \mathrm{C}$ NMR $\delta: 164.5$ (C-12), 153.3 (C-11), 147.6 (C-9), 138.9, 138.7, 138.4 and 137.9 (quat. benzyl), 134.1 (C-3), 132.1 (C-2), 128.6-127.3 (arom. and C-4), 122.3 (C-10), 120.2 (C-1), 82.0 (C-7), 81.6 (C-6), 79.2 (C-8), 75.5 (C-5), 75.3, 74.2, 71.4, $70.4\left(4 \times \mathrm{OCH}_{2} \mathrm{Ph}\right), 62.1$ (C-13), 42.7 (C-14).

HR-MS: $m / z=696.2922$; calcd for $\mathrm{C}_{42} \mathrm{H}_{43} \mathrm{NO}_{7} \mathrm{Na}[\mathrm{M}+\mathrm{Na}]^{+}: 696.2937$.

\subsubsection{Triene 25}

Aldehyde 22 (45 mg) and $\mathrm{Ph}_{3} \mathrm{P}=\mathrm{CHCO}_{2} \mathrm{Me}(54 \mathrm{mg} ; 2.0$ eq.) were dissolved in dry benzene and stirred at room temperature for $16 \mathrm{~h}$. The mixture was concentrated and the product was isolated by column chromatography (hexanes-ethyl acetate, $3: 1 \rightarrow 2: 1)$ as a colorless oil in $74 \%$ yield (36.5 mg) (Figure 7). 
<smiles>C=C/C=C\[C@H](OCc1ccccc1)[C@H](OCc1ccccc1)[C@@H](Cc1ccccc1)[C@H](C=CC(=O)OC)OCc1ccccc1</smiles>

numbering of atoms

Figure 7. The structure of triene $\mathbf{2 5}$ and the numbering of the atoms.

${ }^{1} \mathrm{H}$ NMR $\delta: ~ 7.43-7.18(\mathrm{~m}, 20 \mathrm{H}), 7.01(\mathrm{dd}, J=15.8,6.6 \mathrm{~Hz}, 1 \mathrm{H}, \mathrm{H}-9), 6.45(\mathrm{ddd}, J=16.7,11.2,10.0$ and 6.0 $\mathrm{Hz}, 1 \mathrm{H}, \mathrm{H}-2), 6.26(\mathrm{t}, J=11.2 \mathrm{~Hz}, 1 \mathrm{H}, \mathrm{H}-3), 6.01(\mathrm{~d}, J=15.9 \mathrm{~Hz}, 1 \mathrm{H}, \mathrm{H}-10), 5.45(\mathrm{t}, J=10.3 \mathrm{~Hz}, 1 \mathrm{H}, \mathrm{H}-4)$, $5.26(\mathrm{~d}, J=16.7 \mathrm{~Hz}, 1 \mathrm{H}, \mathrm{H}-1), 5.09\left(\mathrm{~d}, J=10.0 \mathrm{~Hz}, 1 \mathrm{H}, \mathrm{H}-1^{\prime}\right), 4.82\left(\mathrm{~d}, J=11.5 \mathrm{~Hz}, 1 \mathrm{H}, \mathrm{OC} \underline{H}_{2} \mathrm{Ph}\right), 4.63(\mathrm{~m}$, $\left.2 \mathrm{H}, 2 \times \mathrm{OC} \underline{H}_{2} \mathrm{Ph}\right), 4.59-4.53\left(\mathrm{~m}, 2 \mathrm{H}, \mathrm{OC} \underline{H}_{2} \mathrm{Ph}\right.$ and $\left.\mathrm{H}-5\right), 4.51\left(\mathrm{~d}, J=11.3 \mathrm{~Hz}, 1 \mathrm{H}, \mathrm{OC}_{2} \underline{H}_{2} \mathrm{Ph}\right), 4.46(\mathrm{~d}, J=$ $\left.11.5 \mathrm{~Hz}, 1 \mathrm{H}, \mathrm{OC} \underline{H}_{2} \mathrm{Ph}\right), 4.32\left(\mathrm{~d}, J=11.7 \mathrm{~Hz}, 1 \mathrm{H}, \mathrm{OC} \underline{H}_{2} \mathrm{Ph}\right), 4.15\left(\mathrm{~m}, 2 \mathrm{H}, \mathrm{OC}_{2} \mathrm{Ph}\right.$ and $\left.\mathrm{H}-8\right), 3.81(\mathrm{~s}, 3 \mathrm{H}$, OMe), 3.79 (dd, $J=5.6$ and $4.4 \mathrm{~Hz}, 1 \mathrm{H}, \mathrm{H}-7), 3.73(\mathrm{~m}, 1 \mathrm{H}, \mathrm{H}-6)$;

${ }^{13}$ C NMR $8: 166.3$ (C-11), 146.0 (C-9), 138.7, 138.4, 138.1 and 137.8 (quat. benzyl), 133.9 (C-3), 131.8 (C-2), 128.5-127.3 (arom. and C-4), 123.3 (C-10), 120.2 (C-1), 81.6 and 81.5 (C-6 and C-7), 78.8 (C-8), 75.2 $\left(\mathrm{O}^{-} \mathrm{H}_{2} \mathrm{Ph}\right), 75.1(\mathrm{C}-5), 74.1,71.1$, and $70.3\left(3 \times \mathrm{O}^{-} \mathrm{H}_{2} \mathrm{Ph}\right), 51.7(\mathrm{OMe})$.

HR-MS: $m / z=641.2886$; calcd for $\mathrm{C}_{40} \mathrm{H}_{42} \mathrm{O}_{6} \mathrm{Na}[\mathrm{M}+\mathrm{Na}]^{+}: 641.2879$.

\subsubsection{Triene $\mathbf{2 6}$}

This triene was prepared analogously as 25 from aldehyde $22(47 \mathrm{mg})$ and $\mathrm{Ph}_{3} \mathrm{P}=\mathrm{CHCOMe}(55 \mathrm{mg}$; $2.0 \mathrm{eq}$ ) as a colorless oil in $76 \%$ yield ( $36.5 \mathrm{mg}$ ) (Figure 8 ).

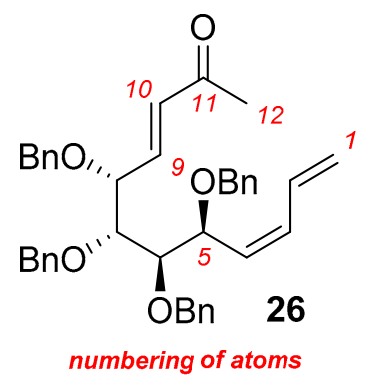

Figure 8. The structure of triene $\mathbf{2 6}$ and the numbering of the atoms.

${ }^{1} \mathrm{H}$ NMR $\delta: 7.36-7.19$ (m, 20H, arom.), 6.78 (dd, $\left.J=16.3,6.5 \mathrm{~Hz}, 1 \mathrm{H}, \mathrm{H}-9\right), 6.46(\mathrm{dt}, J=16.2,10.6 \mathrm{~Hz}, 1 \mathrm{H}$, $\mathrm{H}-2), 6.28(\mathrm{t}, J=11.1 \mathrm{~Hz}, 1 \mathrm{H}, \mathrm{H}-3), 6.18(\mathrm{~d}, J=16.2 \mathrm{~Hz}, \mathrm{H}-10), 5.45(\mathrm{t}, J=10.4 \mathrm{~Hz}, 1 \mathrm{H}, \mathrm{H}-4), 5.27(\mathrm{~d}, J=$ $16.7 \mathrm{~Hz}, 1 \mathrm{H}, \mathrm{H}-1), 5.11\left(\mathrm{dd}, J=10.0\right.$ and $\left.1.7 \mathrm{~Hz}, 1 \mathrm{H}, \mathrm{H}-\mathrm{1}^{\prime}\right), 4.85\left(\mathrm{~d}, J=11.4 \mathrm{~Hz}, 1 \mathrm{H}, \mathrm{OC} \underline{H}_{2} \mathrm{Ph}\right), 4.64-4.56$ $\left(\mathrm{m}, 4 \mathrm{H}, 3 \times \mathrm{OC}_{2} \mathrm{Ph}\right.$ and $\left.\mathrm{H}-5\right), 4.53\left(\mathrm{~d}, J=11.4 \mathrm{~Hz}, 1 \mathrm{H}, \mathrm{OC} \underline{H}_{2} \mathrm{Ph}\right), 4.45\left(\mathrm{~d}, J=11.6 \mathrm{~Hz}, 1 \mathrm{H}, \mathrm{OC} \underline{H}_{2} \mathrm{Ph}\right)$, $4.32\left(\mathrm{~d}, J=11.7 \mathrm{~Hz}, 1 \mathrm{H}, \mathrm{OC} \underline{H}_{2} \mathrm{Ph}\right), 4.18\left(\mathrm{~d}, J=11.6 \mathrm{~Hz}, 1 \mathrm{H}, \mathrm{OC}_{2} \mathrm{Ph}\right), 4.15(\mathrm{ddd}, J=6.5$ and $5.3 \mathrm{~Hz}, 1 \mathrm{H}$, $\mathrm{H}-8), 3.81(\mathrm{t}, J=4.8 \mathrm{~Hz}, 1 \mathrm{H}, \mathrm{H}-7), 3.70(\mathrm{dd}, J=6.3$ and $4.3 \mathrm{~Hz}, 1 \mathrm{H}, \mathrm{H}-6), 2.11(\mathrm{~s}, 3 \mathrm{H}, \mathrm{H}-12)$;

${ }^{13}$ C NMR $8: 198.2$ (C-11), 144.7 (C-9), 138.6, 138.3, 138.1 and 137.8 (quat. benzyl), 134.1 (C-3), 132.6 (C-10), 131.7 (C-2), 128.5-127.4 (arom. and C-4), 120.3 (C-1), 81.7 and 81.6 (C-6 and C-7), 79.3 (C-8), $2 \times 75.3$ (C-5 and $\left.\mathrm{O}_{\mathrm{CH}} \mathrm{Ph}\right), 74.0,71.3,70.3\left(3 \times \mathrm{O}^{\mathrm{C}} \mathrm{H}_{2} \mathrm{Ph}\right), 26.9(\mathrm{C}-12)$.

HR-MS: $m / z=625.2936$; calcd for $\mathrm{C}_{40} \mathrm{H}_{42} \mathrm{O}_{5} \mathrm{Na}[\mathrm{M}+\mathrm{Na}]^{+}: 625.2930$. 


\subsubsection{Weinreb Amide 29}

To a cooled to $0{ }^{\circ} \mathrm{C}$ suspension of MeNHOMe $x \mathrm{HCl}(5.85 \mathrm{~g}, 60.0 \mathrm{mmol}, 3.0 \mathrm{eq})$ in dry $\mathrm{CH}_{2} \mathrm{Cl}_{2}$ (175 mL), a $2 \mathrm{M}$ solution of $\mathrm{Me}_{3} \mathrm{Al}$ in toluene $(30 \mathrm{~mL}, 60 \mathrm{mmol}, 2$ eq.) was added dropwise during $30 \mathrm{~min}$. by a syringe pump. The mixture was stirred for an additional $30 \mathrm{~min}$., then lactone 27 (8.37 $\mathrm{g}$, $20 \mathrm{mmol})$ in dry $\mathrm{CH}_{2} \mathrm{Cl}_{2}(25 \mathrm{~mL})$ was added within $30 \mathrm{~min}$. by a syringe pump, and the mixture was stirred at room temperature for $3 \mathrm{~h}$. Aqueous $\mathrm{H}_{2} \mathrm{SO}_{4}(1 \mathrm{M}$ solution, $100 \mathrm{~mL})$ was carefully added and the organic phase was separated, washed with water $(100 \mathrm{~mL})$, brine $(100 \mathrm{~mL})$, and dried.

Imidazole ( $4.08 \mathrm{~g}, 60 \mathrm{mmol}, 3.0 \mathrm{eq})$ was added to this containing crude 28 and the resulting mixture was cooled to $0{ }^{\circ} \mathrm{C}$. A solution of tert-butyldiphenylchlorosilane $(7.8 \mathrm{~mL}, 30.0 \mathrm{mmol}, 1.5 \mathrm{eq}$.) in $\mathrm{CH}_{2} \mathrm{Cl}_{2}(20 \mathrm{~mL})$ was added dropwise within $1 \mathrm{~h}$ by a syringe pump and the mixture was stirred for additional $16 \mathrm{~h}$. Aqueous $\mathrm{H}_{2} \mathrm{SO}_{4}(1 \mathrm{M}$ solution, $50 \mathrm{~mL})$ was carefully added, the organic phase was separated, washed with water $(100 \mathrm{~mL})$, brine $(100 \mathrm{~mL})$, dried, and the crude product was purified by column chromatography (hexanes-ethyl acetate: $13: 1 \rightarrow 7: 1)$ to give the title product $29(12.35 \mathrm{~g}, 86 \%$ over two steps) as a colorless oil (Figure 9).



Figure 9. The structure of Weinreb amide 29.

${ }^{1} \mathrm{H}$ NMR $\delta: ~ 7.49-7.42$ (m, 3H, arom.), 7.36-7.22 (m, 15H, arom.), 7.18-7.15 (m, 2H, arom.), 4.78-4.71 (m, $\left.2 \mathrm{H}, 2 \times \mathrm{OCH} \underline{H}_{2} \mathrm{Ph}\right), 4.60-4.51\left(\mathrm{~m}, 4 \mathrm{H}, \mathrm{H}-5\right.$ and $\left.3 \times \mathrm{OC}_{2} \underline{H}_{2} \mathrm{Ph}\right), 4.35\left(\mathrm{~d}, J=11.4 \mathrm{~Hz}, 1 \mathrm{H}, \mathrm{OC} \underline{H}_{2} \mathrm{Ph}\right), 3.72-3.65$

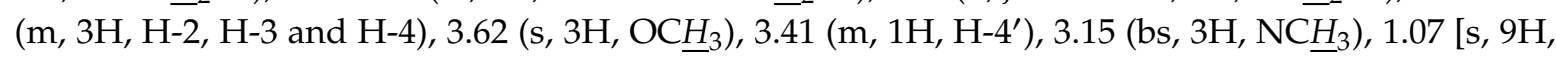
$\left.\mathrm{OSiPh}_{2} \mathrm{C}\left(\mathrm{CH}_{3}\right)_{3}\right]$;

${ }^{13} \mathrm{C}$ NMR $\delta 170.4$ (C-1), 138.5, 138.3 and 138.0 (quat. benzyl), 135.8, 133.3, 129.6 and 129.3-126.5 (arom.), $82.3(\mathrm{C}-3), 79.6(\mathrm{C}-4), 76.1(\mathrm{C}-2), 74.2,73.3$ and $71.6\left(3 \times \mathrm{OC}^{\mathrm{C}} \mathrm{H}_{2} \mathrm{Ph}\right), 61.4\left(\mathrm{O}_{\underline{C H}}\right), 32.8\left(\mathrm{~N}_{3} \mathrm{H}_{3}\right), 26.8$ $\left[\mathrm{OSiPh}_{2} \mathrm{C}\left(\underline{\mathrm{CH}}_{3}\right)_{3}\right], 18.8\left[\mathrm{OSiPh}_{2} \underline{\mathrm{C}}\left(\mathrm{CH}_{3}\right)_{3}\right]$.

HR-MS: $m / z=740.3387$; calcd for $\mathrm{C}_{44} \mathrm{H}_{51} \mathrm{NO}_{6} \mathrm{SiNa}[\mathrm{M}+\mathrm{Na}]^{+}: 740.3383$.

\subsubsection{2,3,4-Tri-O-benzyl-5-O-tert-butyl-diphenylsilyl-D-xylose 30}

To a cooled to $0{ }^{\circ} \mathrm{C}$ solution of amide 29 (2.94 g, $4.10 \mathrm{mmol}, 1.0$ eq.) in dry $\mathrm{Et}_{2} \mathrm{O}(41 \mathrm{~mL})$, $\mathrm{LiAlH}_{4}(0.19 \mathrm{~g}, 5.12 \mathrm{mmol}, 1.25$ eq.) was added in three portions within $15 \mathrm{~min}$. , and the mixture was stirred for $1 \mathrm{~h}$. Aqueous $\mathrm{H}_{2} \mathrm{SO}_{4}(1 \mathrm{M}$ solution, $20 \mathrm{~mL}$ ) was added, the organic phase was separated, washed with water $(20 \mathrm{~mL})$ and brine $(20 \mathrm{~mL})$, dried, and concentrated. The crude product was purified by column chromatography (hexanes $\rightarrow$ hexanes-ethyl acetate: 68:32) to give the aldehyde 30 $(2.05 \mathrm{~g}, 76 \%)$ as a colorless oil (Figure 10). This product was used immediately in the next step.

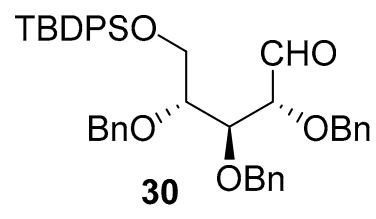

Figure 10. The structure of aldehyde 30.

LR-MS: $m / z=713\left[\mathrm{C}_{43} \mathrm{H}_{50} \mathrm{O}_{6} \mathrm{SiNa}(\mathrm{M}+\mathrm{MeOH}+\mathrm{Na})^{+}\right]$. 


\subsubsection{Silanol 31}

This compound was prepared analogously as 19 , from $30(2.79 \mathrm{~g}, 4.23 \mathrm{mmol})$ as a colorless oil as a mixture of (anticipated) two anti-isomers (Figure 11).<smiles>C=CC(C)C(O)C(OCOS(=O)(=O)OCc1ccccc1)[C@@H](OCc1ccccc1)C(Br)Br</smiles>

Figure 11. The structure of silanol 31.

LR-MS: $m / z=795\left[\mathrm{C}_{48} \mathrm{H}_{60} \mathrm{O}_{5} \mathrm{Si}_{2} \mathrm{Na}(\mathrm{M}+\mathrm{Na})^{+}\right]$.

\subsubsection{Dienoalcohol 32}

This compound was prepared, analogously as 21, from 31. It was purified by column chromatography (hexanes $\rightarrow$ hexanes-ethyl acetate: $36: 64$ ) to give title dienalcohol 32 as a colorless oil (1.36 g, 72\% over two steps) (Figure 12).<smiles>C=C/C=C\[C@H](OBr)[C@@H](OBr)[C@@H](Br)CO</smiles>

numbering of atoms

Figure 12. The structure of diene 32 .

${ }^{1} \mathrm{H}$ NMR $\delta: 7.37-7.22(\mathrm{~m}, 15 \mathrm{H}$, arom.), $6.58(\mathrm{ddd}, J=16.7,11.2$ and $10.1 \mathrm{~Hz}, 1 \mathrm{H}, \mathrm{H}-2), 6.27(\mathrm{t}, J=11.2 \mathrm{~Hz}$, $1 \mathrm{H}, \mathrm{H}-3), 5.53$ (t, $J=10.3 \mathrm{~Hz}, 1 \mathrm{H}, \mathrm{H}-4), 5.29$ (d, $J=16.7 \mathrm{~Hz}, 1 \mathrm{H}, \mathrm{H}-1), 5.16$ (d, J = $\left.10.2 \mathrm{~Hz}, 1 \mathrm{H}, \mathrm{H}^{-1}\right)^{\prime}$ ), $4.78\left(\mathrm{~d}, J=11.4 \mathrm{~Hz}, 1 \mathrm{H}, \mathrm{OC} \underline{H}_{2} \mathrm{Ph}\right), 4.73\left(\mathrm{~d}, \mathrm{~J}=11.4 \mathrm{~Hz}, 1 \mathrm{H}, \mathrm{OC} \underline{H}_{2} \mathrm{Ph}\right), 4.64-4.55(\mathrm{~m}, 4 \mathrm{H}, \mathrm{H}-5 \mathrm{and}$ $\left.3 \times \mathrm{OC}_{2} \mathrm{Ph}\right), 4.35\left(\mathrm{~d}, J=11.7 \mathrm{~Hz}, 1 \mathrm{H}, \mathrm{OC} \underline{H}_{2} \mathrm{Ph}\right), 3.72(\mathrm{ddd}, J=11.3,6.6$ and $4.2 \mathrm{~Hz}, 1 \mathrm{H}, \mathrm{H}-8), 3.69-3.65$ (m, 2H, H-6 and H-7), 3.55 (ddd, $J=11.4,5.6$ and $\left.3.5 \mathrm{~Hz}, 1 \mathrm{H}, \mathrm{H}-8^{\prime}\right), 2.12(\mathrm{t}, J=6.3 \mathrm{~Hz}, 1 \mathrm{H}, \mathrm{OH})$;

${ }^{13} \mathrm{C}$ NMR $\delta: ~ 138.6,138.4$ and 138.1 (quat. benzyl), 133.8 (C-3), 132.0 (C-2), 128.8-127.8 (arom. and C-4), 120.2 (C-1), 82.1 (C-6 or C-7), 79.7 (C-6 or C-7), $75.2\left(\mathrm{O}_{-1} \mathrm{H}_{2} \mathrm{Ph}\right), 74.8(\mathrm{C}-5), 72.8$ and $70.6\left(2 \times \mathrm{OC} \mathrm{H}_{2} \mathrm{Ph}\right)$, $61.7(\mathrm{C}-8)$.

HR-MS: $m / z=467.2180$; calcd for $\mathrm{C}_{29} \mathrm{H}_{32} \mathrm{NO}_{4} \mathrm{Na}[\mathrm{M}+\mathrm{Na}]^{+}: 467.2188$.

\subsubsection{Triene 34}

Alcohol 32 (244 mg, $0.55 \mathrm{mmol}$ ) was oxidized as described for 22 and the resulting product was purified by column chromatography (hexanes $100 \% \rightarrow$ hexanes-ethyl acetate: $1: 2$ ) to afford the corresponding aldehyde $33(204 \mathrm{mg}, 84 \%)$ as an oil. LR-MS: $m / z=497\left[\mathrm{C}_{30} \mathrm{H}_{34} \mathrm{O}_{5} \mathrm{Na}(\mathrm{M}+\mathrm{MeOH}+\mathrm{Na})^{+}\right]$.

This aldehyde $(96 \mathrm{mg}, 0.216 \mathrm{mmol}$ ) was reacted with phosphonate 23 analogously as for 22 . The crude product was purified column chromatography (hexanes $100 \% \rightarrow$ hexanes-ethyl acetate: $90: 10 \rightarrow 20: 80)$ to give the title triene 34 as a colorless oil $(87.3 \mathrm{mg}, 73 \%$ ) (Figure 13$)$. 


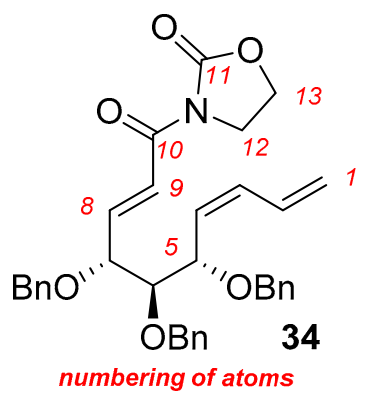

Figure 13. The structure of triene 34 and the numbering of the atoms.

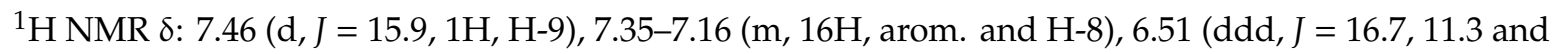
$10.1 \mathrm{~Hz}, 1 \mathrm{H}, \mathrm{H}-2), 6.27(\mathrm{t}, J=11.2 \mathrm{~Hz}, 1 \mathrm{H}, \mathrm{H}-3), 5.45(\mathrm{dd}, J=11.1$ and $9.7 \mathrm{~Hz}, 1 \mathrm{H}, \mathrm{H}-4), 5.25(\mathrm{~d}, J=16.7$, $1 \mathrm{H}, \mathrm{H}-1), 5.09\left(\mathrm{~d}, J=10.1 \mathrm{~Hz}, 1 \mathrm{H}, \mathrm{H}-1^{\prime}\right), 4.74\left(\mathrm{~d}, J=11.5 \mathrm{~Hz}, 1 \mathrm{H}, \mathrm{OC} \underline{H}_{2} \mathrm{Ph}\right), 4.67(\mathrm{~d}, J=11.3 \mathrm{~Hz}, 1 \mathrm{H}$, $\left.\mathrm{OC} \underline{H}_{2} \mathrm{Ph}\right), 4.58-4.30\left(\mathrm{~m}, 6 \mathrm{H}, \mathrm{H}-5, \mathrm{H}-12, \mathrm{H}-12^{\prime}\right.$ and $\left.4 \times \mathrm{OCH}_{2} \mathrm{Ph}\right), 3.97$ (m, 2H, H-13 and H-13'), 3.81-3.74 (m, 2H, H-6 and H-7);


(C-2), 128.5-127.2 (arom. and C-4), 122.5 (C-9), 120.1 (C-1), 82.0 and 79.8 (C-6 and C-7), $75.5\left(\times \mathrm{OCCH}_{2} \mathrm{Ph}\right)$, 75.0 (C-5), 72.4 and $70.4\left(2 \times \mathrm{O}^{-} \mathrm{H}_{2} \mathrm{Ph}\right), 62.1$ (C-12), 42.7 (C-13).

HR-MS: $m / z=553.2456$; calcd for $\mathrm{C}_{34} \mathrm{H}_{35} \mathrm{NO}_{6} \mathrm{Na}[\mathrm{M}+\mathrm{Na}]^{+}: 553.2464$.

\subsubsection{Bicyclic Compound 35}

To a cooled to $-30{ }^{\circ} \mathrm{C}$ solution of $34\left(39.6 \mathrm{mg}, 7.86-10^{-2} \mathrm{mmol}\right)$ in dry $\mathrm{CH}_{2} \mathrm{Cl}_{2}(1.0 \mathrm{~mL})$ a $1.0 \mathrm{M}$ solution of $\mathrm{Me}_{2} \mathrm{AlCl}(118 \mu \mathrm{L}, 0.118 \mathrm{mmol}, 1.5$ eq.) was carefully added and the mixture was stirred for $5 \mathrm{~h}$. Then the mixture was concentrated and the crude product was purified by preparative TLC ( $n$-heptane-MTBE: 6:4) to give the cyclic product 35 as colorless oil (26.9 mg, 68\%) (Figure 14).

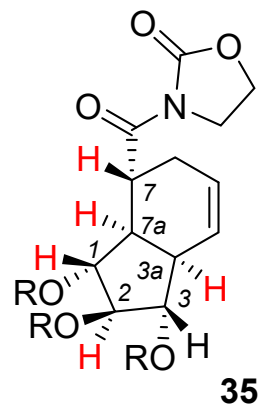

Figure 14. The structure of bicyclic compound 35 and the numbering of the atoms.

${ }^{1} \mathrm{H}$ NMR $\delta: ~ 7.44-7.16$ (m, 15H, arom.), 5.82-5.76 (m, 1H, H-4), 5.68-5.62 (m, 1H, H-5), 4.69-4.58 (m, $\left.4 \mathrm{H}, 4 \times \mathrm{OCH}_{2} \mathrm{Ph}\right), 4.59-4.51\left(\mathrm{~m}, 2 \mathrm{H}, 2 \times \mathrm{OCH}_{2} \mathrm{Ph}\right), 4.34(\mathrm{td}, J=9.0$ and $6.8 \mathrm{~Hz}, 1 \mathrm{H}, \mathrm{H}-10), 4.28(\mathrm{td}, J=9.1$ and $\left.7.0 \mathrm{~Hz}, 1 \mathrm{H}, \mathrm{H}-10^{\prime}\right), 4.03(\mathrm{t}, J=5.0 \mathrm{~Hz}, 1 \mathrm{H}, \mathrm{H}-2), 3.99-3.85(\mathrm{~m}, 3 \mathrm{H}, \mathrm{H}-7, \mathrm{H}-11$ and H-11'), $3.75(\mathrm{t}$, $J=5.5 \mathrm{~Hz}, 1 \mathrm{H}, \mathrm{H}-3), 3.60$ (t, $J=5.6 \mathrm{~Hz}, 1 \mathrm{H}, \mathrm{H}-1), 2.94$ (brs, 1H, H-3a), 2.64 (q, J = 7.2 Hz, 1H, H-7a), 2.26 $(\mathrm{dtd}, J=17.8,4.2$ and $2.0 \mathrm{~Hz}, 1 \mathrm{H}, \mathrm{H}-6), 2.08\left(\mathrm{dtd}, J=17.8,3.8\right.$ and $\left.1.9 \mathrm{~Hz}, 1 \mathrm{H}, \mathrm{H}-6^{\prime}\right)$;



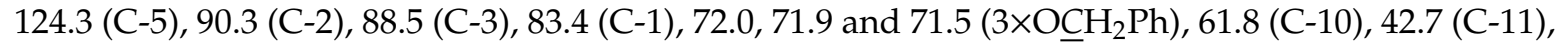
$2 \times 40.4(\mathrm{C}-3 \mathrm{a}$ and C-7a), 36.9 (C-7), 25.8 (C-6).

HR-MS: $m / z=553.2478$; calcd for $\mathrm{C}_{34} \mathrm{H}_{35} \mathrm{NO}_{6} \mathrm{Na}[\mathrm{M}+\mathrm{Na}]^{+}: 553.2464$.

Configuration was established on the basis of 1D NOE (see Figure 1 in the text). 


\section{Conclusions}

We have proposed a convenient and simple route to optically pure bicyclic carbasugar derivatives from D-xylose derivative. The methodology is based on the introduction of the Z-diene system at the anomeric position of a sugar and an olefinic unit at the terminal position. The so obtained triene underwent smooth and highly stereoselective cyclization providing the bicyclic derivative a good yield. The analogous triene prepared from the D-glucose derivative did not, however, undergo any cyclization even under high pressure. We do not know yet the reason for such peculiar behavior.

It is very likely that our methodology leading to bicyclic sugar mimetics can be applied to other simple sugars containing 5 -carbon atoms in the chain. Very problematic, however, is the application of our methodology to hexoses.

Supplementary Materials: The supporting information with the scans of the NMR data of all compounds are available online.

Author Contributions: Most of experimental work-preparation of all starting material and products-was performed by G.W. Analysis of the spectra and done by G.W., M.A.P., and K.T. They performed also some experiments repeating the experimental work of G.W.; A.O.-K. was engaged in the preparation and correction of the manuscript. S.J. highlighted the problem, coordinated the experimental work and wrote the manuscript. All authors have read and agreed to the published version of the manuscript.

Funding: This research received no external funding.

Conflicts of Interest: The authors declare no conflict of interest.

\section{References}

1. Xu, B.; Unione, L.; Sardinha, J.; Wu, S.; Ethève-Quelquejeu, M.; PilarRauter, A.; Blériot, Y.; Zhang, Y.; Martín-Santamaría, S.; Díaz, D.; et al. gem-Difluorocarbadisaccharides: Restoring the exo-anomeric effect. Angew. Chem. Int. Ed. 2014, 53, 9597-9602. [CrossRef] [PubMed]

2. Jiang, C.; Liu, Q.; Liu, J.; Liu, K.; Tian, L.; Duan, M.; Wang, Y.; Shen, Z.; Xu, Y. Selective synthesis of 3-deoxy-5-hydroxy-1-amino-carbasugars as potential $\alpha$-glucosidase inhibitors. Org. Biomol. Chem. 2019, 17, 5381-5391. [CrossRef] [PubMed]

3. Adabala, P.J.P.; Abadi, S.S.K.; Akintola, O.; Bhosale, S.; Bennet, A.J. Conformationally controlled reactivity of carbasugars uncovers the choreography of glycoside hydrolase catalysis. J. Org. Chem. 2020, 85, 3336-3348. [CrossRef]

4. Lillelund, V.H.; Jensen, H.H.; Liang, X.; Bols, M. Recent developments of transition-state analogue glycosidase inhibitors of non-natural product origin. Chem. Rev. 2002, 102, 515-554. [CrossRef]

5. Ganem, B. Glycomimetics that inhibit carbohydrate metabolites. In Carbohydrate Mimics. Concepts and Methods; Chapleur, Y., Ed.; Wiley Online Library: Hoboken, NJ, USA, 1998; pp. 239-258.

6. Cipolla, L.; La Ferla, B.; Airoldi, C. Carbohydrate mimetics and scaffolds: Sweet spots in medicinal chemistry. Future Med. Chem. 2010, 2, 587-599. [CrossRef]

7. Naganawa, H.; Hashizume, H.; Kubota, Y.; Sawa, R.; Takahashi, Y.; Arakawa, K.; Bowers, S.G.; Mahmud, T. Biosynthesis of the cyclitol moiety of pyralomicin 1a in Nonomuraea spiralis MI178-34F18. J. Antibiot. 2002, 55, 578-584. [CrossRef] [PubMed]

8. Jarosz, S.; Tiara, K.; Potopnyk, M. Stereoselective synthesis of sugar mimetics from simple monosaccharides. Pure Appl. Chem. 2019, 97, 1137-1148. [CrossRef]

9. Jarosz, S. From higher carbon sugar to carbocyclic sugar mimics. Curr. Org. Chem. 2008, 12, 985-994. [CrossRef]

10. Jarosz, S.; Błońska, A.; Cmoch, P. Synthesis of highly oxygenated bicyclo [4.3.0] nonanes from sugar allyltins: Model transformations of the adduct derived from D-mannose. Tetrahedron Asymmetry 2008, 19, 1127-1133. [CrossRef]

11. Błońska, A.; Cmoch, P.; Jarosz, S. Sugar allyltins in the synthesis of carbohydrate mimics. Study on the cis-hydroxylation of the bicyclo [4.3.0] nonenes derived from D-mannose. Tetrahedron Asymmetry 2009, 20, 2728-2732. [CrossRef]

12. Jarosz, S.; Szewczyk, K.; Zawisza, A. Synthesis of highly oxygenated enantiomerically pure cis-bicyclo [4.3.0] nonanes from secondary sugar allyltin derivatives. Tetrahedron Asymmetry 2003, 14, 1709-1713. [CrossRef] 
13. Mehta, G.; Ramesh, S.S. Polycyclitols. Novel conduritol and carbasugar hybrids as a new class of potent glycosidase inhibitors. Chem. Commun. 2000, 2429-2430. [CrossRef]

14. Mehta, G.; Ramesh, S.S. Polycyclitols: Synthesis of novel carbasugar and conduritol analogues as potential glycosidase inhibitors. Tetrahedron Lett. 2001, 42, 1987-1990. [CrossRef]

15. Mehta, G.; Ramesh, S.S. Polycyclitols-novel conduritol and carbasugar hybrids as new glycosidase inhibitors. Can. J. Chem. 2005, 83, 581-594. [CrossRef]

16. Witkowski, G.; Jarosz, S. New approach to sugar dienes; useful building blocks for the synthesis of bicyclic derivatives. Synlett 2013, 1813-1817. [CrossRef]

17. Evans, D.A.; Bartoli, J.; Shih, T.L. Enantioselective aldol condensations. 2. Erythro-selective chiral aldol condensations via boron enolates. J. Am. Chem. Soc. 1981, 103, 2127-2129. [CrossRef]

18. Evans, D.A.; Chapman, K.T.; Bisaha, J. Diastereofacial selectivity in intramolecular Diels-Alder reactions of chiral triene- $N$-acyloxazolidones. Tetrahedron Lett. 1984, 25, 4071-4074. [CrossRef]

19. Evans, D.A.; Chapman, K.T.; Bisaha, J. Asymmetric Diels-Alder cycloaddition reactions with chiral $\alpha, \beta$-unsaturated $N$-acyloxazolidinones. J. Am. Chem. Soc. 1988, 110, 1238-1256. [CrossRef]

20. Zhao, W.-B.; Nakagawa, S.; Kato, A.; Adachi, I.; Jia, Y.-M.; Hu, X.-G.; Fleet, G.W.J.; Wilson, F.X.; Horne, G.; Yoshihara, A.; et al. General synthesis of sugar-derived azepane nitrones: Precursors of azepane iminosugars. J. Org. Chem. 2013, 78, 3208-3221. [CrossRef]

21. Langille, N.F.; Dakin, L.A.; Panek, J.S. A mild, chemoselective protocol for the removal of thioketals and thioacetals mediated by Dess-Martin periodinane. Org. Lett. 2003, 5, 575-578. [CrossRef] [PubMed]

22. Reetz, M.T.; Steinbach, R.; Westermann, J.; Peter, R.; Wenderoth, B. Stereoselective addition of organotitanium reagents to carbonyl compounds. Chem. Ber. 1985, 118, 1441-1454. [CrossRef]

23. Hodgson, D.M.; Ying, K.C.; Nuzzo, I.; Freixas, G.; Kulikiewicz, K.K.; Cleator, E.; Paris, J.-M. Intramolecular cyclopropanation of unsaturated terminal epoxides and chlorohydrins. J. Am. Chem. Soc. 2007, 129, 4456-4462. [CrossRef] [PubMed]

24. Dias, L.C.; Melgar, G.Z.; Jardim, L.S.A.A. Short approach to the bicyclo [4.3.0] nonane fragment of stawamycin. Tetrahedron Lett. 2005, 46, 4427-4431. [CrossRef]

25. López, R.; Fernández-Mayoralas, A. Enzymatic $\beta$-galactosidation of modified monosaccharides: Study of the enzyme selectivity for the acceptor and its application to the synthesis of disaccharides. J. Org. Chem. 1994, 59, 737-745. [CrossRef]

Sample Availability: Samples of the compounds are not available from the authors.

(C) 2020 by the authors. Licensee MDPI, Basel, Switzerland. This article is an open access article distributed under the terms and conditions of the Creative Commons Attribution (CC BY) license (http://creativecommons.org/licenses/by/4.0/). 